\title{
Pencitraan Perempuan Pasca Perceraian Dalam Perspektif Gender
}

\author{
Oleh: Ahmad Ali Imron \\ Pesantren Institute Malang \\ Forum Penulis Alumni dan Mahasiswa UIN malang UIN Press \\ Email :imron_arm@yahoo.com
}

\begin{abstract}
Realities of gender inequality often happened in our society life. These are not thought as a problem because of unawareness and insensitivity of it. One of them is stereotype or negative stigma to widow's status. This is formed by social and cultural construction. Public views of widow's image can be analyzed through social and culture as well as concept of gender perspective. Actually most of divorce cases, woman (wife) has more negative impact than a man side. Widow is also identical as second social status. In other gender inequalities, stereotype of widow and widower can be also analyzed if women have function as leader of a family. In fact, they are never categorized as a priority group in development context; the subject as a leader of family is measured by masculinity. It proves that domination of patriarchy culture still influence in many sectors.
\end{abstract}

\section{A. Pendahuluan}

Bentuk-bentuk ketidakadilan gender sering terjadi di lingkungan sekitar kita. Namun, ketidakadilan tersebut tidak dianggap sebagai suatu masalah karena kurang adanya atau bahkan tidak adanya kesadaran dan sensitifitas terhadapnya. Sebut saja misalnya anggapaan dan pelabelan atas predikat janda. Pencitraan gender tentang dua konsep janda dan duda di dalam masyarakat kita tampaknya memiliki makna yang berbeda. Walaupun keduanya secara sosial memiliki status yang sama namun secara kultural mereka dianggap memiliki nilai yang tidak sama. Konotasi "duda" dalam masyarakat kita selalu dianggap hal yang lumrah tidak ada suatu keanehan. Berbeda dengan janda. Predikat janda dalam masyarakat kita masih dianggap label yang janggal terlebih jika status janda tersebut diperoleh bukan karena kematian pasangan hidupnya tetapi karena perceraian dengan pasangannya.

Pada hal terjadinya suatu perceraian itu bukanlah selalu satu-satunya kesalahan yang terletak pada kaum perempuan saja. Nakamura ${ }^{1}$ dalam penelitiannya mengidentifikasikan ada beberapa sebab yang mengakibatkan hancurnya suatu perkawinan, yaitu karena; (1) faktor

\footnotetext{
${ }^{1}$ Nakamura, Hisako. Perceraian orang Jawa : studi tentang pemutusan perkawinan di kalangan orang Islam Jawa / Hisako Nakamura Terj. H. Zaini Ahmad Noeh. Yogyakarta : Gadjah Mada University Press. 1990.
} 
ekonomi, (2) krisis moral, (3) dimadu, (4) meninggalkan, (5) biologis, (6) ada pihak ke tiga, dan juga (7) karena politik. Ikhwal dari hancurnya perkawinan itu suka tidak suka membawa berbagai konsekuensi, baik pada kaum perempuan (istri), laki-laki (suami) dan anak-anak (kalau ada).

Dalam budaya patriarki yang demikian dominan, hancurnya perkawinan selalu membawa dampak dan konotasi negatif terutama bagi kaum perempuan. Artinya, dari kegagalan perkawinannya yang berakhir pada suatu perceraian, menyebabkan pihak perempuan beralih statusnya menjadi seorang janda. Perempuan yang menjadi janda dalam usia relatif muda dan bukan karena kematian pasangan hidupnya seringkali dianggap sebagai perempuan yang kurang baik dan aneh oleh masyarakat. Maka segera saja gosip atau opini negatif tentang sesuatu hal pada seseorang yang berstatus "janda muda" itu akan segera muncul dalam masyarakat.

Topik pembicaraan tentang janda memang tampaknya lebih menarik daripada pembicaraan tentang duda. Bukti demikian menariknya telah muncul berbagai cerita, anekdot dan bahkan buku humor yang banyak mengeksploitasi seputar kehidupan tentang janda. Cerita humor yang dikemas berupa buku kecil ini seringkali pula humornya selalu mengarah pada halhal berbau porno. Dan anehnya, hampir tidak ada pula buku yang dibuat serupa itu untuk kasus tentang kehidupan seorang duda. Dengan demikian stereotipe tentang status janda dan duda itu memang nyata dalam masyarakat kita yang demikian patriarki.

\section{B. Pengelompokan Status Janda}

Secara ilmiah "janda" bisa diartikan seorang perempuan yang pernah melakukan hubungan biologis, tapi dengan alasan tertentu harus hidup tanpa suami. Sedangkan berdasar filsatat bahwa "janda" adalah wanita yang pernah merasakan cinta kasih dan melakukan hubungan intim tapi merelakan cinta kasihnya tidak berlanjut dikarenakan masing-masing memilih jalan hidup sendiri-sendiri untuk memperoleh kebebasan masing-masing tanpa suatu ikatan pernikahan. Namun secara agama bahwa "janda" adalah perempuan mukalaf yang pernah menikah, tapi karena ditakdirkan oleh Allah SWT harus menanggung hidup dan kehidupannya tanpa suami, setelah melewati masa iddah bisa menentukan hidupnya sendiri untuk mengurus dan mengatur anak keturunannya menjadi anak sholeh sebagai ahli waris yang bermanfaat bagi dirinya dan memberi manfaat bagi orang lain.

Di dalam kehidupan masyarakat kita, eksistensi status janda memang mendapatkan pengelompokan dan pandangan tersendiri oleh masyarakat. Diantaranya: pertama, janda karena suaminya meninggal dunia. Biasanya janda seperti ini masih bisa mendapatkan respon yang 
positif dan simpati dari masyarakat lingkungan sekitarnya. Mungkin karena selama berkeluarga, mereka terlihat rukun atau jarang bertengkar, sehingga pada saat suami meninggal dunia, tidak ada gunjingan tentang sebab-sebab suami tersebut meninggal dunia.

Bagi janda yang ditinggal mati oleh suaminya, cenderung untuk tidak menikah lagi. Ini dikarenakan memori dan kenangan yang tersimpan tentang masa lalu bersama suami adalah kenangan yang manis dan indah, sehingga akan sulit terlupakan dan tergantikan dengan sosok laki-laki lain. Bisa juga janda yang demikian ini tidak menikah karena dulu suami memiliki jabatan pekerjaan di instansi pemerintahan dan pihak istri mendapatkan dana pensiun. Apabila janda tersebut menikah lagi, maka dana pensiun tersebut akan hilang.

Kedua, Janda cerai. Seorang wanita yang menjadi janda karena dicerai atau bercerai dengan suaminya. Di masa sekarang dengan angka perceraian yang tinggi, maka janda-janda baru akibat perceraian pun juga menjadi tinggi. Dan kebanyakan bagi janda ini cenderung mendapatkan respon yang negatif, terutama dari pihak ibu-ibu. Mungkin karena mereka berpikir bahwa seorang janda identik dengan kata kesepian, butuh laki-laki untuk teman, dan mereka mengganggap rata-rata janda cerai adalah janda yang gatal, gampangan, dan sederet predikat minus lainnya.

Ketiga, janda kembang. Janda ini adalah janda yang paling disukai laki-laki dan paling dibenci oleh kalangan ibu-ibu. Meskipun janda ini mungkin juga karena ditinggal meninggal suaminya, namun seorang janda kembang adalah janda yang masih muda, dengan atau tanpa anak. Janda demikian sangat rawan dengan godaan, karena selain predikat janda itu sudah minus, ditambah dengan keadaan janda itu yang masih muda menjadikan banyak laki-laki yang ingin mendekati.

Dengan demikian memandang dan memaknai kata "janda" harus dipahami apa yang nyata yang disebut (ontologi), apa yang benar yang disebut (epistemology) dan apa yang sebaiknya dilakukan (axiologi). Sehingga akan mampu menjawab bahwa "kokoh kuatnya suatu negara tergantung pada wanita, bila wanitanya baik maka kuatlah Negara ini” dan mampu menjawab bahwa " surga itu ada di bawah telapak kaki ibu". Namun bila komunitas "janda" terus diberi julukan yang kurang menguntungkan maka wanita akan dihancurkan oleh tuduhan wanita lainnya.

Jadi secara ontologis bahwa "janda" merupakan sosok perempuan yang tidak bersuami, harus menanggung penderitaan secara fisik dan psikis dari berbagai persepsi masyarakat dan lingkungan sekitarnya. Secara epistimologi bahwa "janda" adalah perempuan yang mempunyai fungsi ganda. Disatu sisi sebagai ibu dari keturunan yang ditinggalkan ayahnya, baik melalui perceraian ataupun 
kematian. Dan atau perempuan yang pernah melakukan hubungan biologis dengan lawan jenisnya tapi tidak mendapat perlakuan yang lazim dari pasangannya, sehingga harus melaksanakan fungsi sebagai kepala keluarga. Sedangkan secara axiologi bahwa "janda" harus tetap menjaga harkat dan martabat dirinya ditengah-tengah masyarakat sebagai wanita yang pernah bersuami atau pernah melakukan hubungan biologis dengan pria, sehingga nasib yang dipandang kurang beruntung itu harus mampu survifal ditengah-tengah kehidupan tanpa didampingi pria yang bisa mengayominya. Bahkan menunjukan moral dan akhlakul karimah yang patut dibanggakan. ${ }^{2}$

\section{Realitas Beban Perempuan Janda}

Sebutan "janda", tanpa memandang peringkat kelas sosial, adalah aib. Beragam stigma ditimpakan kepadanya oleh masyarakat yang menganggap tempat perempuan yang "terbaik" adalah di samping suami. Bersamanya beban sosial ditimpakan. Janda karena cerai hidup atau cerai mati, beban sosialnya sama berat. Tanpa pernah mau melihat berbagai faktor penyebab dan kondisi perempuan menjanda, masyarakat cenderung menghakimi dan memberikan label buruk secara sepihak kepada para janda. Tidak heran banyak perempuan mati-matian bertahan dalam perkawinannya meskipun mengalami kekerasan luar biasa. Bahkan para perempuan rela bertahan dalam perkawinan dengan penuh darah karena suami mereka suka memukul hingga babak belur, hanya karena para istri merasa tidak sanggup menyandang status janda.

Meskipun masyarakat lebih bisa menghormati janda karena suami meninggal, tetapi tuntutan terhadap mereka sama besarnya: mereka tidak boleh kawin lagi. "Kawin lagi berarti perempuan 'gatal', berperilaku tidak sesuai dengan gambaran tradisional tentang perempuan". Di samping itu, menjadi janda memang penuh keserbasalahan. Sesama perempuan sering merasa terancam dengan keberadaan janda di sekitarnya karena takut suaminya tergoda sang janda, apalagi kalau janda itu masih muda dan berpenampilan menarik. Di lain pihak, laki-laki cenderung menganggap janda adalah makhluk lemah dan kesepian, yang pantas digoda atau bahkan dimanfaatkan untuk memuaskan syahwatnya. Bahkan sebagian besar orang beranggapan bahwa janda adalah "barang bekas" bernilai rendah. Maka, tidak heran jika kita sering mendengar kata 'janda' dijadikan objek tertawaan dalam banyak kesempatan formal maupun nonformal.

Namun, persoalan "janda" tak hanya itu. Selama puluhan tahun, kedudukan perempuan

${ }^{2}$ Janda Itu Bukan Sampah Masyarakat, 19/05/2009. http://www.pekka.or.id/pdf 
lebih diakui sebagai istri, pendamping suami. Banyak kitab-kitab kebudayaan kuno menempatkan peran perempuan sebatas lima jari tangan, yang semuanya mengandung nilai pengabdian kepada suami. Bahkan negara mengukuhkan ideologi yang sangat bias jender itu secara institusional-politik dan memenjarakan perempuan dalam perannya yang terbatas sebagai pendamping, menjaga keharmonisan keluarga, ibu yang baik, istri yang "hebat". Kalaupun ia bekerja, seberapa pun besarnya, perannya tetap "membantu ekonomi keluarga". Ideologi "istri" ini sangat kuat karena ia merembes ke semua kebijakan pemerintah terhadap perempuan, menyebabkan lemahnya akses perempuan pada sumber daya ekonomi, partisipasi politiknya juga lemah, sehingga suaranya pun tidak terdengar di dalam semua keputusan politik menyangkut kepentingan hidupnya. Maka, ketika perempuan menjadi janda, apalagi kalau ia berasal dari kelompok sosial bawah yang secara riil harus bekerja keras untuk memenuhi kehidupan seluruh keluarga dan berperan sebagai kepala keluarga, di sektor publik seluruh aksesnya dibatasi. Persoalannya menjadi lebih rumit kalau perempuan janda kepala keluarga itu berada di wilayah konflik yang tak kunjung usai, seperti Aceh. Para janda yang suaminya terbunuh dalam konflik, kondisi sosial ekonominya porak-poranda.

Tak banyak orang tahu banyaknya perempuan di Indonesia yang menyandang status janda dan berperan sebagai kepala keluarga. Statistik tahun 2002 menunjukkan jumlah perempuan kepala rumah tangga adalah 13,4 persen dari total rumah tangga di Indonesia. diperkirakan jumlahnya sekitar enam juta kepala keluarga. Bila tiap perempuan kepala keluarga menanggung lima orang, berarti ada 30 juta orang yang harus dihidupi perempuan itu sendirian. Separuh dari jumlah perempuan kepala keluarga itu adalah perempuan sangat miskin dan tidak bisa baca-tulis. ${ }^{3}$

Apapun penyebab perceraian itu, kini pasangan suami-istri beralih status dan menyandang status baru sebagai janda ataupun duda. Untuk kasus perempuan yang berstatus janda seringkali memiliki citra yang buruk, meskipun kesalahan akibat perceraian itu tidak selalu diakibatkan olehnya.

Sebagai orang yang berstatus janda, kadangkala seorang lelakipun enggan untuk menikahinya lagi. Keengganan ini acapkali tidak hanya muncul dari individu si laki-laki saja, bahkan dilegitimasi oleh pihak keluarga laki-lakinya pula, untuk merasa malu bila bermenantukan seorang janda. Lantas kenapa orang malu bermenantukan seorang janda ?.

\footnotetext{
3 “Membongkar Sebuah Dunia Tanpa Suami”, Dalam Kompas, 09 Agustus 2004. SWARA.
} 
Jawabannya karena di dalam masyarakat kita masih mementingkan virginality sebagai sesuatu barang yang harus dipertahankan oleh seorang perempuan dan menjadi ukuran langgeng tidaknya suatu perkawinan. Berbeda halnya dengan status duda, konsep duda jarang sekali dikaitkan dengan virginality oleh masyarakat meskipun sebenarnya secara sosial adalah sama, yaitu sama-sama bekas pakai dan pernah gagal dalam berumah tangga.

Oleh karena adanya bias persepsi dalam masyarakat seperti itu, tampaknya telah menyebabkan kaum perempuan untuk menjadi takut berstatus janda. Ketakutan ini cukup beralasan, selain karena faktor budaya juga terkadang secara ekonomipun perempuan seringkali sangat tergantung pada suaminya. Hasil penelitian Kasto menunjukkan bahwa perempuan yang cerai atau kematian suaminya cenderung untuk hidup menjanda. Kalaupun hendak menikah lagi, mereka lebih menyukai laki-laki yang pernah kawin (duda). Sedangkan laki-laki (duda) lebih banyak memilih perempuan yang belum pernah menikah. ${ }^{4}$ Preferensi demikian, bisa jadi karena kaum laki-laki banyak yang enggan untuk menikahi seorang janda (apalagi telah memiliki anak dari suami pertamanya), selain juga karena adanya keengganan pihak keluarganya untuk memiliki menantu seorang janda tadi. Apalagi bila si laki-laki itu nyata-nyata seorang jejaka, maka rintangan yang harus dihadapi si laki-laki tidak sedikit, hal ini karena masih dianggap sungsang oleh sebagian masyarakat kita bila jejaka hendak menikahi janda. Tetapi sebaliknya, bila seorang duda hendak menikahi seorang gadis hal itu dianggap sah-sah saja.

Fenomena lain, tentang stereotipe janda dan duda ini dapat diamati dari ukuran cepatlambatnya menikah kembali antara janda dan duda. Artinya, bila seorang janda itu cepat menikah kembali dan mendahului mantan suaminya dalam memperoleh jodoh untuk yang kedua kalinya seringkali juga hal ini dianggap sesuatu yang tidak wajar. Maka dianggapnyalah seorang janda itu janda yang genit, sundal dan segudang predikat negatif lainnya. Tetapi sebaliknya bila mantan suaminya yang lebih dahulu menikah, hal ini dianggap wajar dan lumrah oleh masyarakat. Pada hal sebenarnya cepat-lambatnya menikah kembali itu tidak selalu ada kaitannya dengan kegenitan seseorang, semua ini sangat terkait dengan masalah jodoh seseorang.

Oleh karena itu, terjadinya perceraian sebenarnya obyek yang paling menyakitkan dan menakutkan bagi sebagian perempuan, karena dampaknya begitu luas dan predikat yang disandangnyapun cukup membuat gerah setiap orang, karenanya banyak kaum perempuan

\footnotetext{
${ }^{4}$ Kasto. Perkawinan dan perceraian pada masyarakat Jawa: Suatu studi kasus di desa Harjobinangun, Yogyakarta. Yogyakarta: Pusat Penelitian dan Studi Kependudukan, Universitas Gadjah Mada. 1982.
} 
menyerah dan rela untuk " disia-siakan " oleh suaminya asal tidak diceraikan, meskipun disertai dengan tindak kekerasan. Diidentifikasikan ada beberapa hal yang menyebabkan perempuan bertahan dalam posisi seperti itu, antara lain;

1. Mereka merasa kasihan pada suaminya, apalagi mengingat adanya nilai masyarakat bahwa perempuan itu diharapkan dapat merawat, mencintai dan memaafkan, masih kuat.

2. Adanya bujukan dari keluarga atau teman yang meminta untuk bertahan demi anak-anak

3. Faktor ekonomi, artinya perempuan akan merasa kesulitan bila bercerai dalam hal ekonomi, kecuali jika ada keluarga yang akan membantu. (Fentiny dan Yuliarto Nugroho, 1991) ${ }^{5}$.

\section{Janda Dalam Perspektif Gender}

Perspektif gender adalah sudut pandang yang dipakai ketika melakukan penelitian, yang berfungsi untuk memahami gejala sosial budaya, dengan asumsi bahwa di dalam masyarakat ada pembedaan menurut jenis kelamin. Gender sesungguhnya adalah hasil atau akibat dari sexual differentiation. Ada laki-laki dan perempuan, ada domestik publik, dan lain sebagainya yang ada dalam kehidupan sosial.

Terdapat perspektif yang berbeda-beda bagi setiap orang dalam memandang persoalan. Umumnya manusia itu etnosentris, manusia sering berpikir bahwa apa yang dialaminya sama dengan apa yang dialami orang lain, padahal mestinya kita menyadari bahwa dalam dunia yang plural, setiap orang memiliki dunia sendiri-sendiri. Misalnya ketika ada masalah sosial, orang kemudian bertanya itu masalah siapa? Permasalahan bagi kaum laki-laki atau bagi perempuan? Hal ini tergantung pada siapa yang memandang, dan perspektif apa yang digunakan untuk memandang persoalan tersebut ${ }^{6}$.

Sebagaimana yang terjadi pada perempuan yang berpredikat janda, bagi sebagian masyarakat kita masih dianggap memiliki makna negatif. Semisal wanita janda diibaratkan seperti sampah, bekas pakai, dan tidak layak menjadi seorang istri lagi karena atas kegagalan rumah tangganya dahulu. Artinya, seorang janda selalu menjadi kambing hitam dari kegagalan suatu rumah tangga. Fenomena ini secara tidak langsung menunjukkan bahwa posisi perempuan selalu menjadi subordinat dengan lawan jenisnya yang bernama pria itu. Pada hal kegagalan

\footnotetext{
${ }^{5}$ Jandadan duda dalam perspektif jender 2008. didapat pada 19/5/2009 dari http://achmadhidir.blogspot.com/2008/06 ${ }^{6}$ Heddy Sri Ahimsa , Berbagai pendekatan dan analisis gender, makalah TOT, tidak diterbitkan, kerjasama PSW STAIN Malang-PSW IAIN Suka. Yogyakarta (Malang 2002)
} 
perkawinan itu tidak seluruhnya terpikul pada pundak seorang perempuan. Sebab banyak bukti menunjukkan, bahwa justru pihak laki-lakilah seringkali penyebab perceraian itu.

Menurut data dari LBH APIK Jakarta (Lembaga Bantuan Hukum Asosiasi Perempuan Indonesia untuk Keadilan), sepanjang awal tahun hingga akhir februari 2009 mencatat bahwa kasus kekerasan terhadap perempuan sebanyak 160 kasus melalui pengaduan langsung (90 kasus) maupun melalui telepon (70 kasus). Dari 160 kasus itu, 77,8\% atau 130 kasus merupakan kasus Kekerasan Dalam Rumah Tangga (KDRT) dan perceraian merupakan pilihan tertinggi bagi perempuan korban untuk menyelesaikan ataupun memutus rantai kekerasan dalam rumah tangga yang dialaminya.

Prosentase perempuan yang menggugat cerai yakni $49 \%$ dan $3 \%$ suami yang menceraikan korban. Dari angka gugatan cerai perempuan tersebut, 46,8\% nya karena akibat dari nikah siri yang dilakukan suami yang menyebabkan KDRT berupa penelantaran rumah tangga, sedangkan sisanya karena alasan lain. Dari 46,8\% tersebut, 43,4\% nya istri yang dinikah siri mengajukan gugatan perceraian karena menjadi korban penelantaran; dan 56,6\% nya merupakan istri sah yang menjadi korban penelantaran karena suami menikah lagi di bawah tangan/siri. Sementara itu, $16 \%$ perempuan yang mengalami kekerasan dalam rumah tangga dan diceraikan secara tidak sah diancam pidana perzinahan akibat berelasi dengan laki-laki lain ${ }^{7}$.

Ikhwal seperti iti dapat dimaklumi karena di Indonesia masih sangat menjunjung tinggi institusi perkawinan, maka bila terjadi transisi status perkawinan seseorang untuk kemudian menjadi duda atau janda akan memberi citra yang buruk. Dan citra buruk ini selalu pula lebih mengarah pada seseorang yang berlabelkan janda.

Pendifinisian laki-laki dan perempuan dalam konteks ini adalah duda dan janda yang dilakukan oleh masyarakat patriarkhi, sesungguhnya tidak bisa dilepaskan dari tiga konsep metafisika, yakni: identitas, dikotomi dan kodrat. Identitas merupakan konsep pemikiran klasik yang selalu mencari kesejatian pada yang identik. Segala sesuatu harus memiliki identitas, memiliki kategorisasi dan terumuskan secara jelas ${ }^{8}$. Aristoteles yang dikatakan sebagai Bapak identitas, menyatakan bahwa sesuatu tanpa identitas adalah mustahil.

Berdasarkan kategorisasi yang melengkapi atribut identitas, maka lahirlah dikotomi, pembedaan secara rigid dengan batas-batas tertentu. Konsepsi dikotomi yang mewarnai pola

${ }^{7}$ Perempuan Indonesia pilih cerai untuk lepas dari KDRT. 2009. didapat pada 19/05/09 dari: http://langitperempuan.blogspot.com /-naskah.html/

${ }^{8}$ Sumbulah, Umi. Spektrum Gender. Kilasan Inklusi Gender di Perguruan Tinggi. Malang: UIN Malang Press. 2008. 
pikir filsafat barat sejak era klasik hingga modern ini, sesungguhnya lahir dari ide plato. Implikasi dari pola pikir ini adalah adanya penempatan salah satu oposisi dalam posisi subordinat atas yang lain.

Melengkapi konsepsi metafisis di atas, kodrat merupakan penyempurnaanya. Kodrat atau esensi merupakan sesuatu yang diyakini dapat mendasari realita apakah sebuah entitas dikatakan sebagai manusia atau alam. Kodrat adalah sesuatu yang mutlak, given dan tidak dapat dirubah oleh konstruksi dan kekuatan apapun. Tampaknya, wacana gender juga selalu digelayuti oleh persoalan seputar kodrati-non kodrati, terkait dengan peran-peran sosial laki-laki dan perempuan di dunia ini. Oleh karena itu, membicarakan peran gender tanpa mengikutkan teori yang mengkonstruksinya, akan mengakibatkan wacana tersebut akan kehilangan elan vital-nya.

Kolaborasi dan "perselingkuhan" ideologis antara kekuatan patriarkhi —yang diwariskan oleh peradaban kuno — dan metafisika Barat, dapat dijelaskan sebagai berikut:

Patriarkhi mengurung mahluk laki-laki dan perempuan pada kotak-kotak identitas yang tertutup rapat antara satu dengan yang lain. Kompartmentalisas ini diperparah oleh pemaknaan identitas perempuan berdasarkan sudut pandang laki-laki. Perempuan didefinisikan secara sosial, oleh dan untuk kepentingan laki-laki. Berdasarkan kolaborasi dan perselingkuhan kepentingan antara patriarkhi dan metafisika Barat yang melahirkan sejumlah keistimewaan posisi laki-laki dibanding perempuan, maka perlu adanya gerakan penyadaran tidak hanya terhadap perempuan tetapi juga terhadap laki-laki, bahwa patriarkhi, stereotipe, marginalisasi dan sejenisnya yang merupakan sebuah ideologi mapan, ternyata dibangun di atas pondasi yang goyah. Kesadaran kolektif bahwa identitas, dikotomi, dan kodrat yang selama ini dipahami sebagai sesuatu yang given dan absolut, sebenarnya tidak lebih dari sekedar buatan manusia. Pandangan perempuan dan laki-laki, satu sama lain tentang diri mereka masing-masing merupakan pengkondisian yang dibentuk oleh masyarakat secara seksis. Pandangan dan konstruk yang seksis tersebut akan bertahan dan memengaruhi cara berpikir, baik terhadap perempuan maupun laki-laki.

Studi eksplorasi tentang stereotipe gender yang dilakukan oleh William dan Best selama rentangtahun 1982, 1990 dan $1992^{9}$ di tigapuluh (30) kebudayaan yang berbeda mengindikasikan bahwa 100 (seratus) mahasiswa laki-laki dan perempuan di tiap-tiap negara tersebut membuat semacam konsensus peran gender yang berbeda. Ternyata, laki-laki meyakini memiliki tipikal sifat yang tinggi dalam hal dominasi, otonomi, agresi, suka menonjolkan diri, prestasi tinggi dan

\footnotetext{
${ }^{9}$ Smith, Peter B. \& Bond Michael Harris. 1994. Social Psychology Across Cultures; analyzis and perspectives. Massachusetts: Allyn and Bacon.
} 
ketahanan mental yang luar biasa. Sementara para wanita justru sebaliknya, yaitu yakin bahwa self-preference yang tinggi justru terdapat pada rasa rendah diri (abasesment), afiliasi, rasa hormat dan dalam hal penyapihan atau pengasuhan anak. Walaupun demikian, William dan Best menegaskan bahwa derajat konsensus yang tinggi lebih bayak muncul pada budaya kolektif, sementara pada struktur budaya individualias sebagaimana budaya barat, derajat konsensus stereotipe gender lebih rendah dan menurun. Oleh karenanya mereka menyimpulkan bahwa terdapat korelasi yang kuat antara individualisme dan rendahnya konsensus tentang stereotipe gender.

Bercermin pada temuan-temuan tersebut, tidak dapat disangkal lagi bahwa beberapa aspek citra baku gender merupakanpencerminan distribusi perempuan dan laki-laki ke dalam beberapa peran yang dibedakan. Proses pembentukan citra ini muncul seiring dengan perubahan zaman. Pada zama dahulu, dengan prinsip the survival of the fittest, proses fisik menjadi prasyarat bagi penguasaan struktur sosial. Sebagai akibatnya, perempuan secara fisik tidak memiliki kemampuan dan sosok sebagaimana dipunyai laki-laki menjadi termarginalisasi dari sektor persaingan budaya. Hampir seluruh aspek kehidupan sosial lebih banyak mendefinisikan kelaki-lakian/maskulinitas ${ }^{10}$.

Pandangan stereotipe tersebut pada akhirnya menjadi akhir masalah ketidakadilan gender dan perlakuaan diskriminasi terhadap perempuan. Ketidakadilan gender itu sendiri dapat menjelma dalam proses stereotipe, marginalisasi (kondisi terpinggirkan), subordinasi (posisi selalu dibawah dan tidak berdaya), bertambahnya beban kerja tidak hanya sekedar di sector domestik tetapi juga di sektor publik, serta fenomena kekerasan terhadap perempuan, seperti pelecehan, perkosaan, penganiayaan dan lain-lain.

MacCormack dan Strathern ${ }^{11}$, menjelaskan bahwa terbentuknya dominasi laki-laki atas perempuan dapat ditinjau dari teori nature and culture. Menurut teori ini, dikotomi nature dan culture mengarah kepada perubahan nature menuju culture. Dalam proses transformasi dari nature ke culture seringkali terjadi penaklukan. Laki-laki yang digambarkan sebagai culture mempunyai wewenang untuk menaklukkan dan memaksakan kehendaknya kepada perempuan (nature). Asumsi ini menunjukkan bahwa secara kultural laki-laki memang ditempatkan pada posisi yang lebih tinggi daripada perempuan. Maka, secara langsung maupun tidak langsung hal

\footnotetext{
${ }^{10}$ Soemandoyo, Priyo. (1999). Wacana Gender dan Layar Televisi (studi perempuan dalam pemberitaa televisi swasta). Yogyakarta: The Ford Foundation - LP3Y.

${ }^{11}$ MacCormack, C.P. and M. Strathern. Nature, Culture and Gender. Cambridge: Cambridge University Press. 1980.
} 
ini tentu berpengaruh terhadap cara pandang, penilaian atau perilaku masyarakat dalam kehidupan keluarga maupun kehidupan sosial budaya. Teori tersebut memberikan gambaran bahwa aspek sosiokultural telah membentuk tatanan sosial (social structure) dan persepsi sosial (social perception) yang kondusif bagi dominasi stereotipe masyarakat atas keberadaan perempuan, khususnya yang berpredikat janda (akibat bercerai).

Pembedaan citra antara status janda dengan duda bukan merupakan masalah bagi kebanyakan orang. Namun, pembedaan ini menjadi masalah ketika menghasilkan ketidaksetaraan di mana laki-laki (duda) memperoleh dan menikmati kedudukan yang lebih baik dan menguntungkan daripada perempuan (janda). Lebih jauh pembedaan citra janda dan duda telah menjadi landasan ketidaksetaraan tersebut, karena masyarakat memandang perempuan janda lebih rendah daripada laki-laki duda.

Historisitas adanya pembedaan gender terhadap citra Janda ini, terjadi melalui proses yang sangat panjang dan beragam. Pembentukan gender ditentukan oleh sejumlah faktor yang membentuk, kemudian disosialisasikan, diperkuat dan bahkan dikontruks melalui sosial atau kultural, dan dilanggengkan oleh mitos-mitos maupun interpretasi agama. Di sinilah akar penyebab utama dianggapnya perbedaan gender sebagai suatu kewajaran atau kodrati yang tidak bisa dirubah dan dipertukarkan antara kedua jenis makhluk tersebut. Sehingga melahirkan ketidakadilan gender (gender inequalities) baik bagi kaum laki-laki maupun perempuan. Perbedaan gender tidak menjadi masalah sepanjang tidak melahirkan ketidakadilan, tetapi ternyata yang menjadi persoalan adalah karena perbedaan gender ini seringkali menimbulkan ketidakadilan. Perjuangan melawan ketidakadilan adalah keharusan sejarah. Kendati demikian, untuk mewujudkannya selalu mendapatkan tantangan. Hal ini karena adanya ketakutan beberapa pihak yang pro-kemapanan dan telah diuntungkan oleh sistem budaya yang cenderung berpihak dan menguntungkan laki-laki, dan berpusat pada kaum laki-laki (male sentris) ${ }^{12}$.

Pencitraan terhadap perempuan berpredikat janda adalah contoh ketidakadilan gender yang selama ini tidak/kurang disadari sebagai masalah, baik oleh laki-laki maupun perempuan sendiri. Untuk itulah diperlukan upaya penyadaran gender baik bagi laki-laki maupun perempuan. Adapun bentuk ketidakadilan gender yang dimaksud adalah stereotipe.

Stereotipe adalah pelabelan terhadap kelompok, suku, bangsa tertentu yang selalu berkonotasi negatif sehingga sering merugikan dan menimbulkan ketidakadilan. Pelabelan atau

\footnotetext{
${ }^{12}$ Sumbulah, umi. Spektrum Gender.....Op.cit hlm. 12
} 
penandaan yang dikaitkan dengan perbedaan jenis kelamin tertentu (perempuan) akan menimbulkan kesan negatif yang merupakan keharusan yang disandang oleh perempuan ${ }^{13}$. Pelabelan negatif ini kendati lebih bernuansa mitos daripada realitas, ternyata muncul dalam berbagai aspek kehidupan dan berbagai media budaya Indonesia. Pelabelan atau pencitraan tersebut dikemas dari mulai bentuknya yang sama sekali tidak ilmiah sampai yang terkesan ilmiah (pseudo ilmiah) ${ }^{14}$.

Stereotipe merupakan salah satu bentuk ketidakadilan gender. Misalnya suatu dugaan bahwa perempuan itu suka bersolek untuk menarikperhatian lawan jenis. Jika terjadi kasus perkosaan, selalu disimpulkan bahwa kejadian tersebut berawal dari label perempuan, tanpa harus menganalisis dari sisi-silain yang menjadi faktor penyebabnya. Karena itu, kasus perkosaan dipandang sebagai kesalahan perempuan. Ia dianggap sebagai sumber fitnah terjadinya perkosaan. Tidak terkecuali kekerasan yang terjadi dalam rumah tangga, perempuan sering dianggap sebagai penyebabnya, misalnya isteri dipukul karena cerewet tidak cerdas, atau ditinggal kawin lagi karena ia kurang cantik, tidak dapat bersolek dan sebagainya. Semua itu berangkat dari stereotipe perempuan secara umum. Demikian pula, perempuan adalah jeneis manusia yang lemah fisik maupun intelektualnya sehingga tidak layak menjadi pemimpin, karena ia memiliki keterbatasan, tidak seperti laki-laki yang memiliki aktivitas lebih leluasa bebas dan produktif.

Dalam beberapa hal, masyarakat menghubungkannya dengan mitos agama yang salah, misalnya perempuan tempatnya fitnah, mayoritas penghuni neraka, tidak sederajat dengan lakilaki, dan sebagainya, memperpanjang daftar stereotipe perempuan yang kemudian disosialisasikan dari generasi ke generasi. Proses demikian itu secara berangsur-angsur membentuk citra diri setiap perempuan bahwa stereotipe dipandang sebagi kodrat yang tidak dapat diubah sedikitpun. Karena itu tidaklah heran menjadi tidak mudah diperdayakan, mudah menyerah, inferior, tidak memiliki semangat mandiri, dan tidak bisa mengambil keputusan untuk dirinya sendiri.

Hal ini tidak saja mempersulit perempuan untuk berkreasi dan mengembangkan potensi diri, tetapi juga menyulitkan perempuan untuk keluar dari garis batas pencitraan negatifnya. Jalaluddin rahmat bahkan menambah daftar panjang citra negatif perempuan dengan mengungkap kasus pelabelan negatif dalam teori dan analisis kejiwaan perempuan dalam disiplin

\footnotetext{
${ }^{13}$ Mufidah, C.h. Paradigma Gender. Malang: Bayumedia Publishing. 2003.

${ }^{14}$ Ibid, hlm. 14
} 
psikologi ${ }^{15}$.

\section{E. Penutup}

Menyandang status janda, apa pun masalahnya, sering dianggap sebagai produk gagalnya perkawinan. Kasus seperti itu tidak dimonopoli salah satu golongan rumah tangga. Siapa pun pasangan suami istri itu, dari mana pun mereka berasal, bila tidak ada lagi komitmen dalam perkawinan, bisa saja terjadi perceraian. Itu berarti pihak perempuan (istri) merugi karena menyandang status janda. Dalam masyarakat yang masih mengagungkan tingginya nilai perkawinan, perceraian memang membuat pasangan suami-istri mendapat tantangan berat, baik itu dari masyarakat sekitar maupun dari keluarga. Keinginan untuk berusaha melanjutkan hidup setelah dihadapkan pada keretakan rumah tangga, ternyata, juga memiliki dampak sosial yang cukup besar, terutama bagi pihak perempuan. Apalagi statusnya sebagai single parent. Menyandang status sebagai janda merupakan hal berat secara psikologis apalagi stigma status janda selalu dianalogikan dengan hal negatif.

Perempuan berstatus Janda sama halnya dengan perempuan lain pada umumnya, butuh rasa aman, nyaman dan bahagia. Mereka memang tak lagi memiliki ikatan dengan lelaki dalam sebuah pernikahan, tetapi kegagalan yang menimpa mereka bukanlah sebuah alasan untuk memandang rendah status baru yang disandangnya. Sekali lagi, tak ada seorang pun yang menikah untuk sebuah perceraian.

Terjadinya perceraian sebenarnya obyek yang paling menyakitkan dan menakutkan bagi sebagian perempuan, karena dampaknya begitu luas dan predikat yang disandangnyapun cukup membuat gerah setiap orang, karenanya banyak kaum perempuan menyerah dan rela untuk " disia-siakan " oleh suaminya asal tidak diceraikan, meskipun disertai dengan tindak kekerasan.

Sementara itu dalam prakteknya, orang tua yang memiliki anak perempuan berstatus jandapun ternyata lebih prihatin daripada ia memiliki anak laki-laki yang berstatus duda. Keprihatinan ini lebih disebabkan karena anaknya menjadi single parents. Menurut Wignyosoebroto (1994) ${ }^{16}$, di Indonesia, ditaksir jumlah keluarga demikian (sekalipun tak semuanya terjadi akibat perceraian) berada pada angka 6,5 \% dari jumlah total yang ada.

\footnotetext{
${ }^{15}$ Sumbulah, umi. Spektrum Gender.....Op.cit hlm. 14

${ }^{16}$ Op. cit: Janda dan duda dalam perspektif jender 2008. didapat pada 19/5/2009 dari http://achmadhidir.blogspot.com/2008/06
} 
Keluarga single parent seperti ini tentu saja merupakan ajang hidup yang sangat kurang menguntungkan, baik secara ekonomi maupun secara sosial secara sempurna. Dilaporkan di kawasan Asia Pasifik, bahwa insiden kekurangan gizi di kalangan anak-anak sering tak hanya disebabkan oleh tingkat kesejahteraan keluarga yang rata-rata rendah, akan tetapi juga disebabkan oleh penelantaran-penelantaran seperti itu.

Letak ketimpangan stereotipe dalam masyarakat terhadap janda dan duda juga dapat diamati bila seorang perempuan berfungsi sebagai kepala keluarga (misal karena menjanda) tetapi dalam kenyataan mereka ini sering tidak masuk dalam hitungan dalam konteks pembangunan. Karena konsep kepala keluarga selalu diukur dengan status laki-laki. Karena di Indonesia budaya patriarki masih dominan. 


\section{Daftar Pustaka}

Kasto. Perkawinan dan perceraian pada masyarakat Jawa: suatu studi kasus di desa Harjobinangun, Yogyakarta. Yogyakarta: Pusat Penelitian dan Studi Kependudukan, Universitas Gadjah Mada. 1982.

MacCormack, C.P. and M. Strathern. Nature, Culture and Gender. Cambridge: Cambridge University Press. 1980.

Mufidah, C.h. Paradigma Gender. Malang: Bayumedia Publishing. 2003.

Nakamura, Hisako. Perceraian orang Jawa : studi tentang pemutusan perkawinan di kalangan orang Islam Jawa / Hisako Nakamura Terj. H. Zaini Ahmad Noeh. Yogyakarta : Gadjah Mada University Press. 1990.

Sumbulah, Umi. Spektrum Gender. Kilasan Inklusi Gender di Perguruan Tinggi. Malang: UIN Malang Press. 2008

Janda Itu Bukan Sampah Masyarakat, www.pekka.or.id, 19/05/2009

Perempuan Indonesia pilih cerai untuk lepas dari KDRT. 2009. didapat pada 19/05/09 dari: http://langitperempuan.blogspot.com /-naskah.html/

.http://achmadhidir.blogspot.com/2008/06/janda-dan-duda-dalam-perspektif-jender.html

Membongkar Sebuah Dunia Tanpa Suami Harian Kompas, 09 Agustus 2004 